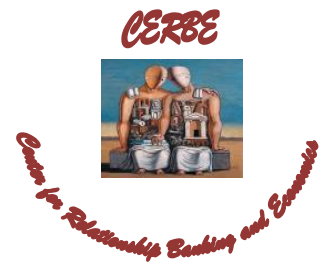

Libera Università Maria SS. Assunta

CERBE Working Paper Series

BANK LENDING TECHNOLOGIES AND SME CREDIT RATIONING IN EUROPE IN THE 2009 CRISIS

Giovanni Ferri, Pierluigi Murro and Zeno Rotondi

Working Paper No. 5

February 2016

Center for Relationship Banking and Economics

Department of Economic and Political Sciences and of Modern Languages

LUMSA University

Via Pompeo Magno, 22, 00192 Rome - Italy

https://sites.google.com/site/cerbelumsa/home

(C) G. Ferri, P. Murro and Z. Rotondi. The aim of the series is to diffuse the research conducted by CERBE Fellows. The series accepts external contributions whose topics are related to the research fields of the Center. The views expressed in the articles are those of the authors and cannot be attributed to CERBE. 


\title{
Bank Lending Technologies and SME Credit Rationing in Europe in the 2009 Crisis*
}

\author{
Giovanni Ferri ${ }^{a}$, Pierluigi Murro ${ }^{a \dagger}$ Zeno Rotondi $^{b}$ \\ ${ }^{a}$ Lumsa University \\ ${ }^{b}$ UniCredit
}

\begin{abstract}
The first wave of the global financial crisis hit Europe in the last part of 2008 and through 2009. With banks in a tailspin, credit rationing intensified - as measured in various different ways particularly for the small and medium sized enterprises (SMEs). The extent of such retrenchment in the supply of credit could reflect not only the worsened general condition of the European banks but also vary at the micro level depending on the lending technologies being used in the SME-main bank rapport. Using the EFIGE database, we examine SME credit rationing in seven EU countries (Austria, France, Germany, Hungary, Italy, Spain and the UK) and try to assess the extent to which differences in the lending technologies and in the status of the firm-main bank relationship contributed to the phenomenon. We find that a firm matching with a bank using the transactional lending technology was more likely to end up rationed for credit during the first part of the financial crisis.
\end{abstract}

JEL Codes: G21, D82, G30

Keywords: Bank-Firm Relationships, Asymmetric Information, Credit Rationing.

\section{Introduction}

Credit availability for small and medium enterprises (SMEs) is a topic of significant research interest among academics and a crucial issue for policy makers (Berger and Udell, 2006). In the last years, the global financial crisis particularly affected SMEs. In fact, due to their opacity SMEs are particularly sensitive to reductions in the supply of credit. With immature capital markets and little or no corporate bond finance, banks are by far the main provider of external funds (Popov and Udell, 2012). The bank lending survey of the European Central Bank (ECB) confirms that the financial crisis substantially reduced the provision of credit by banks to SMEs in the Euro area (Vermosen et al., 2013). In fact, a simple look at the evolution of the credit conditions tells us that banks' loan supply to SMEs significantly tightened from the fourth quarter of 2007 and particularly in 2008 and early 2009 (Figure 1). In this first wave of the crisis, though the extent of the credit restriction was somewhat larger for the three peripheral countries considered (Italy, Portugal and Spain) vis-à-vis the three core countries considered (France, Germany and the Netherlands), the two groups experienced qualitatively analogous trends. Thereafter, the degree of restriction almost stopped increasing until the second quarter of 2010. However, from the third quarter of 2010 to the first quarter of 2012 the two groups moved in opposite directions. While the degree of restriction did not increase or even decreased for the core countries, it started increasing again intensely for the countries at the periphery. Finally, since the second quarter of 2012 the degree of restriction seemed to ease in both groups. The retrenchment in the loan supply during the crisis is believed to have contributed to depress the real economy of the Eurozone and particularly that of the peripheral countries. Small and medium-sized enterprises account for a large share of economic activity in industrialized countries

\footnotetext{
${ }^{*}$ The views put forward in the paper belong exclusively to the authors and do not involve in any way the institutions of affiliation.

${ }^{\dagger}$ Corresponding author: p.murro@lumsa.it 
and are particularly important in the European business sector. In 2013, for example, in the United Kingdom firms with less than 250 employees accounted for about 58 percent of total employment. In manufacturing, in France firms with less than 250 employees accounted for 54 percent of total employment, and in Germany for 46 percent of total employment (Eurostat, 2014).

The aim of this paper is to venture into an empirical analysis of the transmission of the (unexpected) financial shock coming from the first wave of the global crisis. In particular, we investigate whether the extent of individual firm credit rationing in 2009 - the time of most intense loan supply restriction - was affected by the lending technologies employed by the main bank of that firm. We do that referring to the large EFIGE database, covering seven countries: five of them belonging to the Eurozone (Austria, France, Germany, Italy and Spain) and two outside the Eurozone (Hungary and the UK). Following what reported by the interviewed firm, we distinguish whether her main bank adopts a transactional lending technology or a relational lending technology. Furthermore, still based on what the interviewed firm indicates, we know whether her main bank bases its lending decisions on the collection and processing of soft information. Finally, we interact the lending technology variable with the soft information variable.

Following the literature (see, e.g., Bartoli et al., 2013; Berger and Udell, 2006) we try to test whether, ceteris paribus, a firm matching with a transactional lending main bank was more likely to end up rationed for credit in 2009 (H1). We also verify three sub-hypotheses. First, we check whether the extent of credit rationing is lower when the firm couples with a relational main bank (sub-H1). Second, we test if the likelihood of rationing for the borrowing firm doesn't increase if her transactional main bank engages in gathering and processing soft information (sub-H2). Third, we verify whether collecting and using soft information will reduce rationing if the main bank adopts a relational lending technology (sub-H3). To anticipate, our results bring: (i) strong support for H1; (ii) no support for sub-H1; (iii) no support for sub-H2; (iii) some support for sub-H3.

In the remainder of the paper, Section 2 draws on the relevant literature providing a reference framework for our study. In Section 3 we describe our data and methodology. Section 4 reports and comments our main results. Finally, in Section 5 we synthesize the main thrust of the paper and try to draw the main policy implications.

\section{Survey of the Literature}

Among academics there is the perception that SMEs, due to their opaqueness, lack appropriate financing and need to receive special support, such as government programs that increase lending ${ }^{1}$ Unsurprisingly, SMEs are largely dependent on banks for their external finance. Banks lend to SMEs by means of a variety of technologies. Berger and Udell (2006) define a lending technology as a unique combination of primary information source, screening and underwriting policies/procedures, loan contract structure, and monitoring strategies/mechanisms. Among the various lending technologies used to finance SMEs, the literature has thus far focused on two classes: transaction-based lending technologies and relationship lending technologies (see, e.g., Berger and Udell, 2006, Bartoli et al., 2013). These two lending technologies are normally distinguished by the information that the bank uses in granting and monitoring the loan. Transactional lending technologies are based primarily on hard information (quantitative information, such as that derived from balance sheets and/or collateral guarantees), while relationship lending technologies assigns a key role to soft information (qualitative information obtained via personal interaction). The literature suggests that large banks hold a comparative advantage in transactional lending, while the smaller or local banks have an edge in relationship lending (Stein, 2002). Moreover, the conventional view in the literature is that relationship lending is the obvious way to manage the opaqueness of SMEs (De la Torre at al., 2010).

Boot (2000) defines relationship lending as "the provision of financial services by a financial intermediary that: i. invests in obtaining customer-specific information, often proprietary in nature; and ii. evaluates the profitability of these investments through multiple interactions with the same customer over time and/or across products". This definition relies on two main aspects: eliciting

\footnotetext{
${ }^{1}$ See, for example, Berger and Udell (1998) and De la Torre et al. (2010) for a discussion of how opaqueness can affect bank lending.
} 
the release of "proprietary" information from the client to the bank and the presence of multiple interactions between the two parties. Several papers have analyzed the impact of relationship lending on the financing of the SMEs. ${ }^{2}$ On data for Italy, Angelini et al. (1998) find that the intensity of relationship banking reduces the probability of rationing, even though the lending rates charged by the banks tend to increase as the firm-bank relationship lengthens. Bartoli et al. (2011) find evidence that during the harshest phase of the 2008 Financial Crisis Italian banks tended to support borrowers characterized by more intense informational tightness. For the US, Cole (1998) finds that a lender is less likely to grant credit to a firm if the customer relationship has lasted for one year or less, or if the firm deals with other financial counterparts. Considering Belgian enterprises, Degryse and Van Cayseele (2000) identify the role of relationship banking along two different dimensions: borrowing rates increase with the length of the firm-bank relationship, while borrowing rates decrease when the scope of the firm-bank relationship - defined as the purchase of additional information intensive services (other than the loan) - increases. For Germany, Hainz and Wiegand (2013), analyze the role of relationship lending during the 2008 Financial Crisis. The authors, considering all three aspects of a loan contract - quantity, cost and collateral - find that, although the availability of credit is not affected, the cost of credit and collateral requirements are reduced when a main bank relationship exists.

In the latest years, both the theoretical and the empirical literatures have started to study also the transaction lending technologies. In particular, some authors suggest that transaction lending is not a single homogeneous lending technology but should be separated into a number of distinct transaction technologies used by financial institutions. Berger and Udell (2006) underline that transactions technologies include financial statement lending, small business credit scoring, asset-based lending, factoring, fixed-asset lending, and leasing. They define and describe each of these lending technologies, highlight its distinguishing features, and show how the technology addresses the opacity problem. Also the empirical literature tries to explain the transaction-based lending technologies. For example, Berger and Frame (2007) study the use of credit scoring for SMEs and its effects on credit availability. Klapper (2006) tests the role of factoring for financing SMEs, showing that factoring may allow a high-risk supplier to transfer its credit risk to higher quality buyers.

Finally, some recent studies (see, e.g., Berger and Udell 2006; Beck et al. 2011; Ferri and Murro 2015) have begun to discuss the conventional view that suggests that more centralized and hierarchical organizational structures can have a negative impact on lending to SMEs. These authors propose a new paradigm for bank SME finance, arguing that large banks can be as effective in SME lending through transactional lending technologies and centralized organizational structures instead of relationship lending. Uchida et al. (2006) tested the importance of the various lending technologies. Their results suggest that the banks, even though possibly employing mainly some specific criteria to lend, tend to use the various lending technologies at the same time. Using Italian data, Bartoli et al. (2013) obtain similar results. These results confirm that the same firm tends to receive credit via different lending technologies. However, an additional finding shows that more soft information is produced when the bank uses relationship lending technology as the primary technology individually or coupled with transactional lending technologies. Thus, it appears that the way soft information becomes embodied in the lending decision might still differ between relational vs. transactional banks/technologies.

\section{$3 \quad$ Data and methodology}

\subsection{Empirical methodology and data description}

We analyze the role of lending technologies and soft information on credit rationing. To test our hypotheses we start building an empirical model of the probability that firms are rationed in the credit market. Denote $y_{1}^{*}$ the amount of credit the firm would wish to obtain and $y_{2}^{*}$ the size of the loan actually granted by the bank, we have that the firm is rationed any time $y^{*}=\left(y_{1}^{*}-y_{2}^{*}\right)>0$.

\footnotetext{
${ }^{2}$ See Bongini et al. (2015) for a survey on the empirical literature on Relationship Lending.
} 
Thus, we can model the probability of rationing as:

$$
\begin{aligned}
& y= \begin{cases}1 & \text { if } y^{*}>0 \\
0 & \text { otherwise }\end{cases} \\
& y^{*}=x a_{1}+z_{1} d_{11}+u_{1},
\end{aligned}
$$

where $y$ is our measure of credit rationing (a dummy variable taking value one if the firm is rationed and zero otherwise), $x$ is a vector of the lending technologies used by the main bank, $z_{1}$ is a vector of control variables, and $u_{1}$ is the residual.

Our main data source is the EU-EFIGE dataset, a database collected within the EFIGE project (European Firms in a Global Economy: internal policies for external competitiveness) supported by the Directorate General Research of the European Commission through its 7th Framework Programme and coordinated by the Bruegel Institute. This database combines measures of firms' international activities (e.g., exports, imports, FDI) with quantitative and qualitative information on R\&D, innovation, labor organization, financing and organizational activities. The data consists of a representative sample (at the country level for the manufacturing industry) of almost 15,000 surveyed firms (above 10 employees) in seven European economies (Austria, France, Germany, Hungary, Italy, Spain, the United Kingdom). The data was collected in 2010, covering the years from 2007 to 2009. Special questions related to the behavior of firms during the crisis were also included in the survey. The data collection was performed through a survey carried out by a professional Contractor, with the aim of gathering both qualitative and quantitative information at the firm level. The questionnaire submitted to the firms covers six different broad areas: a) the firm ownership structure; b) workforce characteristics (skills, type of contracts, domestic vs. migrant workers, training); c) investment, technological innovation, R\&D (and related financing); d) export and internationalization processes; e) market structure and competition; f) financial structure and bank-firm relationships. Moreover, to ensure standard statistical representativeness of the collected data, the dataset was built so as to fulfill two main criteria: 1) the availability of an adequately large target sample of firms, initially set at around 3,000 firms for large countries (France, Germany, Italy, Spain and the UK), and some 500 firms for smaller countries (Austria and Hungary); 2) a proper stratification of the sample in order to ensure representativeness of the collected data ex-ante and ex-post for each country, considering in particular three dimensions: sector composition, regions and size class ${ }^{3}$

Table 1 presents some descriptive statistics. At the mean, the surveyed firms have been in business for 34 years; beyond $60 \%$ of them have fewer than 50 employees (below $4 \%$ of the firms have more than 500 employees); $22 \%$ of them are part of a group. The majority of firms are located in Germany, France, Italy and Spain ( $80 \%$ of the total), while $14 \%$ of the firms are located in UK, $3.3 \%$ in Hungary and $3 \%$ in Austria; alternatively, $82.7 \%$ of the firms belong to the Eurozone. Moving on to their financial set up, the average length of the relationship with the main bank is 16 years, on average firms have three banks and the share of loans obtained from the main bank is $59 \%$ of the total banking loans received. On average $4 \%$ of the firms in the sample are rationed (see below Sub-Section 3.3 for the definition of rationing). Moreover, this percentage is larger (8.8\%) if we consider the weak definition of rationing, while only $2.4 \%$ of the firms are "strong" rationed. Table 1 shows also the summary statistics of the two lending technology indices (see below Sub-Section 3.2). The lending factors related to transactional technology are relatively more frequently emphasized, in fact the mean of the index of transactional lending is 0.469 , while the mean for the relational index is 0.268 . This result shows that transactional lending is the most widespread lending technology. Table 2 shows the summary statistics of the bank variables for each country in the sample. Considering the relationship of the firm with the banking system, the data shows that the relationship length with the main bank is longest in Austria and Germany (23.5 and 22.6 years respectively) while Hungary and Spain are the countries with the shortest average relationship length (8.9 and 13.5 years). As shown in the literature (see, for example, Ongena and Smith, 2000), Italy and Spain are the countries with, on average, more bank relationships per firm (4.2 and 4.3), while the firms in the UK have only 1.4 bank relationships on average. Italy and Spain are also the countries with the largest percentage of credit rationed firms

\footnotetext{
${ }^{3}$ For more information about the survey, see Altomonte and Aliquante (2012).
} 
(7.6 and 8.5\%). The transactional lending technology seems to be more important in Hungary and the UK, and marginal in Germany. Instead, the importance of relational lending is larger in France and Austria, and secondary in Italy.

\subsection{Lending technology indices}

We consider two indicators of lending technology similar to those in Bartoli et al. (2013) ${ }^{4}$ We capture the characteristics of the different lending technologies using the question "Which type of information does the bank normally use/ask to assess your firm's credit worthiness?" (F.16 in the EFIGE survey). In answering this question the firm was required to choose among seven factors (with the possibility of multiple answers, see the Appendix). Most of these factors are related to one of the lending technologies. We then link the factors more closely associated with each lending technology based on the Berger and Udell (2006) classification scheme. We focus on the two macro classes of lending technologies from this classification: transactional lending and relationship lending 5

To consider the transactional technology we use two of the seven criteria (balance sheet information and historical records of payments and debt service) that represent quantitative information for the bank. From these two factors we created the transactional lending index, as the average of the two dummy variables which take a value of one if the firm chose them as relevant lending factors by the main bank. The virtue of using an average index is that it can be directly compared with the other index since both the indices are constructed from dummy variables and thus take a value in the $[0,1]$ range. As explained in Section 2, under relationship lending, the bank relies primarily on private information gathered through contact over time with the firm, its owner and the local community to address the opacity problem. We construct the relationship lending index using the factors that seem most related to private information accumulation by banks through close relationships. The index is an average of two dummy variables which take a value of one if the firm chose as relevant information: interviews with the management on firm's policy and prospects and brand recognition.

\subsection{Credit rationing, soft information and control variables}

To define our indicators of credit rationing, we use the firms' answers to two questions of the survey that are not necessarily related to the main bank. The questions are: A) "During the last year, did the firm apply for more credit?" (F.13 in the EFIGE survey) and B) "To increase its borrowing, was the firm prepared to pay a higher rate of interest?" (F.14 in the EFIGE survey). We construct three variables of credit rationing. The first one is a dummy variable taking value one if the firm answers "Yes, applied for it but was not successful" to question A), zero otherwise. Moreover, we use two other proxies for credit rationing: weak credit rationing and strong credit rationing. We classify the firm as weakly credit rationed, if it answers question A) "Yes, applied for it but was not successful" or "No, did not apply for it" (in this way we consider as rationed also the firms discouraged from applying for new credit). Finally, strong credit rationing is a dummy variable taking value one if the firm answers yes also to question B), zero otherwise.

In order to construct a proxy variable for the production of soft information we employ a methodology similar to that used in Scott (2004) and Uchida et al. (2012). We use the question of the survey: "Which characteristics are key in the choice of a main bank?" (F.12 in the EFIGE survey). In answering this question the firm had to choose among nine factors (see the Appendix for the details on this question). We focus on the following characteristics: the bank offers also a consultancy on strategic financial decisions, the bank has a long-lasting relationship with the firm. The variable Soft is the

\footnotetext{
${ }^{4}$ These indices, based on previous literature (see, e.g., Uchida et al., 2006, Murro, 2010), are imperfect proxies for the use of different lending technologies, since they are based on the firms' perception of the lending factors used by the bank in granting its loans, and thus may be capturing the banks' screening process imprecisely. However, constructing these indices using the firms' perspectives has some advantages. Previous researches on SME finance suffer from the problem that the lending technologies are usually not identified (Kano et al., 2011). Our data allows us to perceive the actual features of the bank at the time the firm is asked. Thus, we can distinguish between lending technologies.

${ }^{5}$ Berger and Udell (2006) consider six different transaction-based lending technologies: (i) financial statement lending, (ii) small business credit scoring, (iii) asset-based lending, (iv) factoring, (v) fixed-asset lending, and (vi) leasing, together with relationship lending.
} 
average for the two dummy variables that take value one if the firm chose the above characteristics, zero otherwise.

Finally, we discuss the other variables included in the regressions. To account for the fact that more productive and larger firms are less likely to be rationed, we include labor productivity, measured as the value added per worker and firm size (the log of total employees). We also include a dummy variable indicating whether the firm belongs to a group, the age of the firm, the degree of financial leverage, given by the ratio of total loans to the sum of the total loans and the firm's assets, and the capital intensity (fixed assets per worker). Finally, we control for the country in which the firm is located. In particular, we include a country fixed effect and GDP per capita in the country in 2009.

\subsection{Hypotheses to be tested}

Following the literature we entertain one main hypothesis and three alternative sub-hypotheses. Our main hypothesis is that, ceteris paribus, a firm matching with a transactional lending main bank has a larger probability to end up rationed for credit in 2009 (H1). This hypothesis descends from considering that the problems due to asymmetric information are magnified during a deep recession such as that of 2009 (e.g., De Haas and Van Horen, 2013; Kremp and Sevestre, 2013). Let's now turn to the three sub-hypotheses. First, based on the strand of literature underscoring the potential beneficial effects of relationship lending in terms of firm access to bank credit (Boot, 2000; Degryse et al., 2009), we could expect that the extent of credit rationing is lower when the firm couples with a relational main bank $(s u b-H 1)$. Second, the likelihood of rationing for the borrowing firm might not increase if her transactional main bank engages in gathering and processing soft information, according to the literature on "hardening of soft information" (Petersen, 2004; Berger and Udell, 2006) (sub-H2). The third and last hypothesis we contemplate - in the spirit of Bartoli et al. (2013) is that collecting and using soft information will reduce rationing if the main bank adopts a relational lending technology but not if it is a transactional bank (sub-H3).

\section{Results}

In this section we investigate the impact of lending technologies and soft information on the probability that a firm is credit rationed. As just outlined, we test one main hypothesis. Following the literature on SME financing, we expect that, ceteris paribus, the firm in relation with a main bank that prefers using transactional lending technology has a larger probability to be credit rationed. In fact, as asymmetric information is magnified during a deep recession, the more opaque SMEs could be suffer more credit rationing. Indeed, we try to study three sub-hypotheses. First, based on the papers that suggest the positive role of relationship lending for the firm access to bank credit, we suppose that the probability of credit rationing is lower when the firm couples with a relational main bank. Second, in line with the hypothesis of "hardening of soft information", the extent of credit rationing might not increase for the firms with a transactional main bank that is able to use also the soft information. Finally, we test whether collecting and using soft information will reduce rationing if the main bank adopts a relational lending technology but not if it is a transactional bank.

Tables 3-5 report the results for the three measures of credit rationing. In particular, Table 3 shows the regressions in which we consider the simple measure of credit rationing as dependent variable. Instead, Tables 4 and 5 display the results for the weak and strong measures of credit rationing. In column 1 of Table 3, we study the effect of relational and transactional lending technologies on credit rationing. In columns 2 and 3 we insert also the proxy for soft information (Soft). Finally, in columns 4-6 we include the interactions terms among the lending technologies and Soft. The findings show that transactional lending has a positive and significant impact on credit rationing in all the regressions. This is in line with the theoretical predictions that the probability of credit rationing is larger when the main bank prefers to use the transactional lending technology (strong support for H1). The coefficient of transactional lending is significant at the $1 \%$ level and economically sizable. We also find that relational lending has no significant negative effect on credit rationing (no support for $s u b-H 1)$. Finally, the results in columns 2 and 3 show that the emphasis put on soft information by 
the firm can reduce credit rationing. This is consistent with findings in the literature that underline the positive role of soft information for borrowers (e.g. Uchida et al., 2012).

As for the control variables, the results illustrate that bigger firms are significantly less likely to be rationed. The coefficient on capital intensity (defined as the ratio of total assets to the number of employees) is significantly positive. Instead, labor productivity seems to reduce the likelihood of rationing. Interestingly, we find a strong positive and significant effect for leverage (given by the ratio of total loans to the sum of the total loans and the firm's assets). As expected, firms in countries with higher GDP are less likely to be rationed. Finally, belonging to a group and a longer age of the firm appear to have not significant effect on rationing.

In columns 4-6 of Table 3, we investigate the impact of soft information on the probability that a firm is credit rationed, depending on the lending technology used by the firm's main bank. In order to perform this analysis we interact our proxy of soft information (Soft) with the lending technology adopted by the firm's main bank. If hardening of soft information were feasible, we would expect that the interactions between Soft and the lending technologies would have a statistically significant impact and bear the same sign on the probability of being credit rationed. As expected, the interaction between Soft and relationship lending is larger than the interaction with transactional lending. Moreover, the interaction with relational lending is significant in column 4 (some support for $s u b-H 3$ ) whereas the Soft-Transactional interaction is never significant (no support for $s u b-H 2)$. This finding confirms the third sub-hypothesis, which suggests that soft information is still more valuable in the case of relationship lending.

In Table 4 and 5, we report analogous regressions where we consider the weak and strong measures of credit rationing. The results for the strong measure of credit rationing are qualitatively similar. Instead, the findings for the weak measure of credit rationing are less robust, although transactional lending still has a positive and significant effect on credit rationing.

\section{Conclusions}

The first wave of the global financial crisis - emanating from the US subprime debacle and the bankruptcy of Lehman - hit Europe in the last part of 2008 and through 2009. With banks in a tailspin, credit rationing intensified - as measured in various different ways - particularly for the small and medium sized enterprises (SMEs). The extent of such retrenchment in the supply of credit could reflect not only the worsened general condition of the European banks but also vary at the micro level depending on the lending technologies being used in the SME-main bank rapport.

Using the EFIGE database, we examined SME credit rationing in seven EU countries (Austria, France, Germany, Hungary, Italy, Spain and the UK) and tried to assess the extent to which differences in the lending technologies and in the status of the firm-main bank relationship contributed to the phenomenon. In a large sample - depending on the specification from a minimum of 3,600 to a maximum of 6,800 units - of enterprises, we proved that the use of transactional lending technologies generally worsened credit rationing throughout the entire sample. On the contrary, the use of relational lending technologies heightened credit rationing in no specification. Furthermore, in line with what Bartoli et al. (2013) found for Italy, also across this European level sample we rejected the hypothesis that there might be no disadvantage for large banks providing credit to opaque SMEs if they use transaction lending technologies well-suited to these enterprises, such as SME credit scoring, asset-based lending, factoring, fixed-asset lending, and leasing (Berger and Udell, 2006). In fact, the production of soft information proved to lower the probability of credit rationing only when associated with a relationship lending technology.

Our findings have a bearing not only for a better understanding of the historical economic dynamics in 2009 but offer potential suggestions in view of the following second wave of instability centered around the sovereign EU crisis - as well as on the prospect for the Eurozone Banking Union. Specifically, in the face of external shocks the ability of banks to know better their borrowers' true risk class - owing to production of soft information and use of it via relationship lending - can attenuate the extent to which the shock is transmitted to the real economy. Two issues then arise. First, maybe we need better theories to represent banking with extensive consequences for regulation, supervision 
and business practice (Ferri and Neuberger, 2014). Second, instead of relying solely on the mechanistic method of the risk weighted asset approach (e.g., Basel 2 and 3), regulation should probably encompass also banking business models in evaluating the true risk behind banks (Ayadi et al., 2012).

\section{References}

[1] Alexandre, H., Bouaiss, K., Refait-Alexandre, C. (2014). Banking relationships and syndicated loans during the 2008 financial crisis, Journal of Financial Services Research 46(1), 99-113.

[2] Altomonte, C., Aquilante, T. (2012). The Eu-Efige/ Bruegel-Unicredit Dataset. Bruegel Working Paper.

[3] Angelini, P., Di Salvo, R., Ferri, G. (1998). Availability and Cost of Credit for Small Businesses: Customer Relationships and Credit Cooperatives, Journal of Banking \& Finance 22, 925-954.

[4] Ayadi, R., Arbak, E., de Groen, W.P. (2012). Regulation of European banks and business models: Towards a new paradigm?, Brussels: CEPS.

[5] Bartoli, F., Ferri, G., Murro, P., Rotondi, Z. (2011). Soft Information and Loan Supply in the Crisis: Evidence from the Credit Files of a Large Bank, Rivista Bancaria 5-2011, 7-28.

[6] Bartoli, F., Ferri, G., Murro, P., Rotondi, Z. (2013). SME financing and the choice of lending technology in Italy: Complementarity or substitutability?, Journal of Banking \& Finance 37, $5476-5485$.

[7] Beck, T., Demirgüç-Kunt, A., Martinez Peria, M.S. (2011). Bank Financing for SMEs: Evidence Across Countries and Bank Ownership Types, Journal of Financial Services Research 39, 35-54.

[8] Berger, A.N., Frame W.S. (2007). Small business credit scoring and credit availability, Journal of Small Business Management 46, 5-22.

[9] Berger, A.N., Frame, W.S., Miller, N.H. (2005a). Credit scoring and the availability, price, and risk of small business credit, Journal of Money, Credit \& Banking 37, 191-222.

[10] Berger, A.N., Miller, N.H., Petersen, M.A., Rajan, R.G., Stein, J.C. (2005b). Does function follow organizational form? Evidence from the lending practices of large and small banks, Journal of Financial Economics 76, 237-269.

[11] Berger, A.N., Udell, G.F. (1995). Relationship Lending and Lines of Credit in Small Firm Finance, Journal of Business 68, 351-81.

[12] Berger, A.N., Udell, G.F. (1998). The economics of small business finance: The roles of private equity and debt markets in the financial growth cycle, Journal of Banking \& Finance 22, 613-673.

[13] Berger, A.N., Udell, G.F. (2006). A more complete conceptual framework for SME finance, Journal of Banking \& Finance 30, 2945-2968.

[14] Bongini, P., Di Battista, M.L., Nieri, L. (2015). Relationship lending through the cycle: what can we learn from three decades of research?, mimeo.

[15] Boot, A.W.A. (2000). Relationship banking: what do we know?, Journal of Financial Intermediation $9,7-25$.

[16] Cole, R.A. (1998). The Importance of Relationships to the Availability of Credit, Journal of Banking \& Finance 22, 959-977.

[17] Degryse, H., Kim, M., Ongena, S. (2009). Microeconometrics of Banking, Oxford University Press. 
[18] De Haas, R., Van Horen, N. (2013). Running for the Exit? International Bank Lending During a Financial Crisis, The Review of Financial Studies 26, 244-285.

[19] De la Torre, A., Martinez Peria, M.S., Schmukler, S.L. (2010). Bank involvement with SMEs: Beyond relationship lending, Journal of Banking \& Finance 34, 2280-2293.

[20] EUROSTAT (2014). Structural business statistics, Luxembourg.

[21] Ferri, G., Murro, P. (2015). Do Firm-Bank "Odd Couples" Exacerbate Credit Rationing?, Journal of Financial Intermediation 24, 231-251.

[22] Ferri, G., Neuberger, D. (2014). The banking regulatory bubble and how to get out of it, Rivista di Economia Politica 2-2014, 36-69.

[23] Hainz, C., Wiegand, M. (2013). How does relationship banking influence credit financing? Evidence from the financial crisis. Ifo Working Papers, 157.

[24] Kano, M., Uchida, H., Udell, G. F., Watanabe, W. (2011). Information verifiability, bank organization, bank competition and bank-borrower relationships, Journal of Banking \& Finance 35, 935-954.

[25] Klapper, L. (2006). The role of factoring for financing small and medium enterprises, Journal of Banking \& Finance 30, 3111-3130.

[26] Kremp, E., Sevestre, P. (2013). Did the crisis induce credit rationing for French SMEs?, Journal of Banking \& Finance 37, 3757-3772.

[27] Murro, P. (2010). Lending Technologies in Italy: an Example of Hardening of Soft Information, Rivista Bancaria 4-2010, 7-32.

[28] Ongena, S., Smith, D.C. (2000). Bank relationships: A review. In P.T. Harker and S.A. Zenios, editors, Performance of Financial Institutions. Cambridge University Press.

[29] Petersen, M. (2004). Information: Hard and Soft, Northwestern University, mimeo.

[30] Popov, A., Udell, G. (2012). Cross-border banking, credit access, and the financial crisis, Journal of International Economics 87, 147-161.

[31] Stein, J. C. (2002). Information production and capital allocation: Decentralized vs. hierarchical firms, Journal of Finance 57, 1891-1921.

[32] Uchida, H., Udell, G. F., Yamori, N. (2006). SME financing and the choice of lending technology, RIETI Discussion Paper Series 06-E-025, Research Institute of Economy, Trade, and Industry.

[33] Uchida, H., Udell, G. F., Yamori, N. (2012). Loan officers and relationship lending to SMEs, Journal of Financial Intermediation 21, 97-122.

[34] Vermosen, V., Deloof, M., Laveren, E. (2013). Long-term debt maturity and financing constraints of SMEs during the Global Financial Crisis, Small Business Economics 41, 433-448. 


\section{Appendix}

Figure 1. Degree of restriction in loan supply to SMEs in the Eurozone: Core vs. Periphery

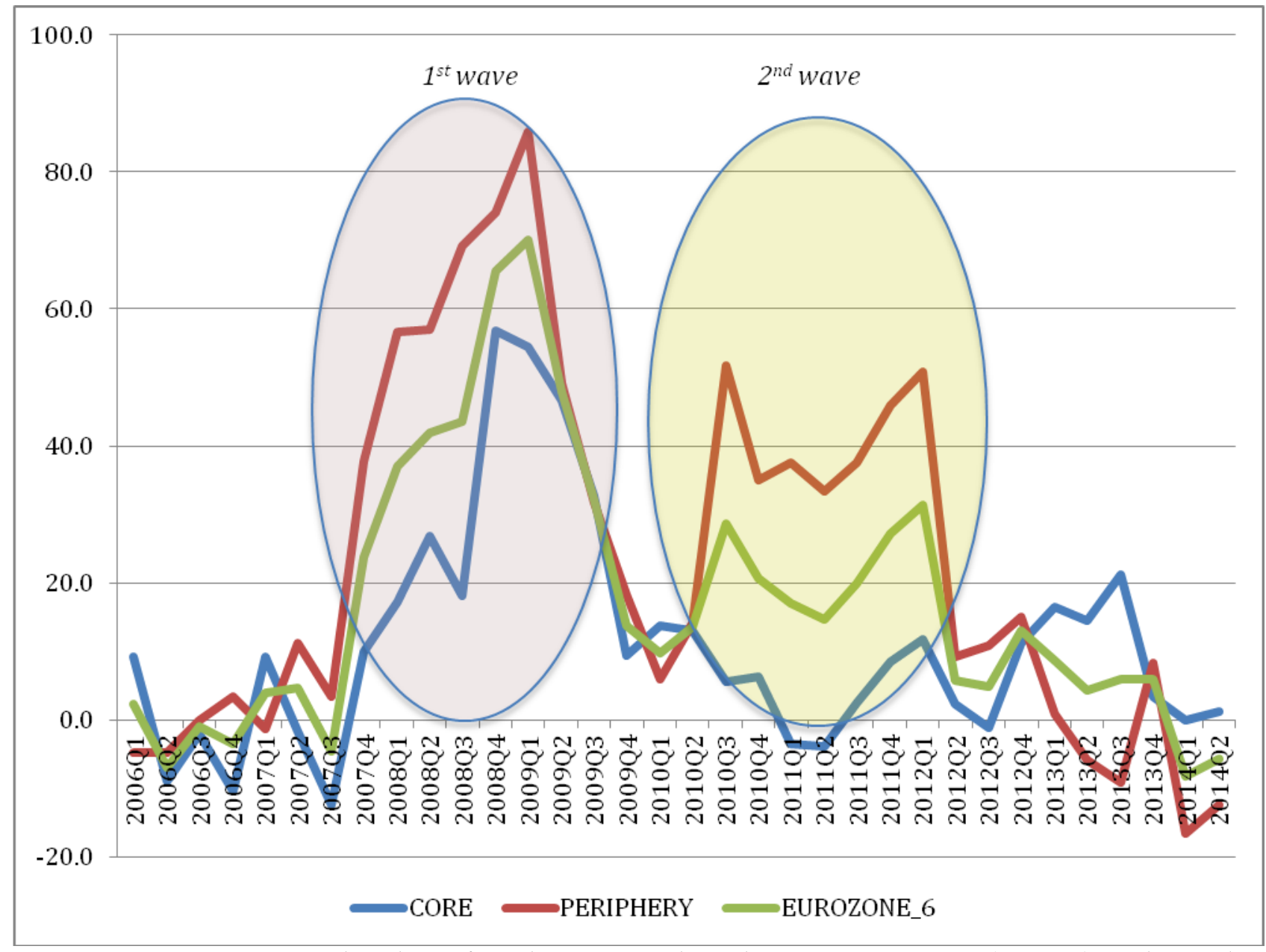

Source: Our computations on data drawn from the ECB's Bank Lending Survey. A positive (negative) number implies increasing (decreasing) degree of restriction of banks' loan supply to SMEs by the equivalent percentage. CORE = simple mean of France, Germany, the Netherlands; PERIPHERY = simple mean of Italy, Portugal, Spain; EUROZONE_6 = simple mean of France, Germany, Italy, the Netherlands, Portugal, Spain. 
Table 1. Summary statistics: full sample

\begin{tabular}{|c|c|c|c|c|c|}
\hline Variables & $\begin{array}{l}\text { Number of } \\
\text { Observations }\end{array}$ & Mean & $\begin{array}{l}\text { Standard } \\
\text { Deviation }\end{array}$ & Min & $\operatorname{Max}$ \\
\hline \multicolumn{6}{|c|}{ Dependent Variables } \\
\hline Rationing * & 14,760 & 0.040 & 0.196 & 0 & 1 \\
\hline Weak rationing $*$ & 14,760 & 0.088 & 0.284 & 0 & 1 \\
\hline Strong rationing * & 14,760 & 0.024 & 0.154 & 0 & 1 \\
\hline \multicolumn{6}{|c|}{ Bank variables } \\
\hline Transactional lending & 9,135 & 0.469 & 0.391 & 0 & 1 \\
\hline Relational lending & 9,127 & 0.268 & 0.330 & 0 & 1 \\
\hline Soft information & 8,911 & 0.289 & 0.350 & 0 & 1 \\
\hline Relationship length & 6,758 & 16.104 & 14.029 & 1 & 99 \\
\hline Number of banks & 14,655 & 3.089 & 2.531 & 1 & 60 \\
\hline Share of the main bank & 6,874 & 58.922 & 33.138 & 0 & 100 \\
\hline \multicolumn{6}{|c|}{ Control variables } \\
\hline Age & 14,726 & 34.532 & 30.629 & 0 & 368 \\
\hline Number of employees & 8,819 & 129.863 & $4,130.988$ & 1 & 386,170 \\
\hline Group * & 14,760 & 0.221 & 0.415 & 0 & 1 \\
\hline Leverage & 11,665 & 0.374 & 0.117 & 0 & 0.999 \\
\hline Italy $*$ & 14,760 & 0.205 & 0.403 & 0 & 1 \\
\hline Austria * & 14,760 & 0.030 & 0.171 & 0 & 1 \\
\hline France * & 14,760 & 0.201 & 0.401 & 0 & 1 \\
\hline Germany * & 14,760 & 0.199 & 0.399 & 0 & 1 \\
\hline Hungary * & 14,760 & 0.033 & 0.179 & 0 & 1 \\
\hline Spain * & 14,760 & 0.192 & 0.394 & 0 & 1 \\
\hline UK * & 14,760 & 0.140 & 0.347 & 0 & 1 \\
\hline
\end{tabular}

Note: $*$ denotes a $(0,1)$ dummy variable.

Table 2. Summary statistics of bank variables

\begin{tabular}{|c|c|c|c|c|c|c|c|c|c|c|c|c|c|c|}
\hline & \multicolumn{2}{|c|}{ Italy } & \multicolumn{2}{|c|}{ Austria } & \multicolumn{2}{|c|}{ France } & \multicolumn{2}{|c|}{ Germany } & \multicolumn{2}{|c|}{ Hungary } & \multicolumn{2}{|c|}{ Spain } & \multicolumn{2}{|c|}{ UK } \\
\hline & Mean & Std. Dev. & Mean & Std. Dev. & Mean & Std. Dev. & Mean & Std. Dev. & Mean & Std. Dev. & Mean & Std. Dev. & Mean & Std. Dev. \\
\hline Rationing & 0.076 & 0.265 & 0.016 & 0.125 & 0.015 & 0.122 & 0.015 & 0.120 & 0.033 & 0.178 & 0.085 & 0.279 & 0.005 & 0.069 \\
\hline Weak rationing & 0.126 & 0.332 & 0.045 & 0.208 & 0.040 & 0.197 & 0.058 & 0.233 & 0.061 & 0.240 & 0.109 & 0.311 & 0.134 & 0.340 \\
\hline $\begin{array}{l}\text { Strong rationing } \\
\text { Transactional }\end{array}$ & 0.044 & 0.204 & 0.011 & 0.106 & 0.008 & 0.089 & 0.008 & 0.090 & 0.020 & 0.142 & 0.056 & 0.230 & 0.002 & 0.049 \\
\hline $\begin{array}{l}\text { lending } \\
\text { Relational }\end{array}$ & 0.615 & 0.265 & 0.634 & 0.293 & 0.414 & 0.395 & 0.169 & 0.336 & 0.691 & 0.343 & 0.665 & 0.285 & 0.731 & 0.332 \\
\hline lending & 0.203 & 0.296 & 0.478 & 0.358 & 0.526 & 0.293 & 0.133 & 0.285 & 0.376 & 0.376 & 0.279 & 0.307 & 0.428 & 0.321 \\
\hline Soft information & 0.409 & 0.335 & 0.129 & 0.228 & 0.625 & 0.359 & 0.037 & 0.138 & 0.083 & 0.186 & 0.419 & 0.341 & 0.213 & 0.254 \\
\hline $\begin{array}{l}\text { Relationship } \\
\text { length }\end{array}$ & 16.178 & 12.447 & 23.522 & 20.226 & 17.497 & 14.350 & 22.674 & 19.179 & 8.903 & 5.826 & 13.569 & 10.020 & 15.374 & 17.211 \\
\hline $\begin{array}{l}\text { Number of } \\
\text { banks }\end{array}$ & 4.195 & 2.808 & 2.444 & 1.947 & 2.577 & 1.763 & 2.677 & 2.313 & 1.799 & 1.182 & 4.369 & 2.949 & 1.445 & 1.082 \\
\hline $\begin{array}{l}\text { Share of the } \\
\text { main bank } \\
\text { Domestic local }\end{array}$ & 45.602 & 26.137 & 72.743 & 33.300 & 58.367 & 31.503 & 72.805 & 31.466 & 74.911 & 36.832 & 55.248 & 31.225 & 78.224 & 36.968 \\
\hline $\begin{array}{l}\text { bank } \\
\text { Domestic }\end{array}$ & 0.680 & 0.467 & 0.640 & 0.481 & 0.847 & 0.360 & 0.784 & 0.411 & 0.266 & 0.443 & 0.534 & 0.499 & 0.140 & 0.347 \\
\hline national bank & 0.845 & 0.362 & 0.489 & 0.500 & 0.737 & 0.440 & 0.396 & 0.489 & 0.703 & 0.457 & 0.782 & 0.413 & 0.869 & 0.338 \\
\hline Foreign bank & 0.040 & 0.197 & 0.047 & 0.213 & 0.152 & 0.359 & 0.038 & 0.191 & 0.066 & 0.248 & 0.044 & 0.205 & 0.086 & 0.280 \\
\hline
\end{tabular}


Table 3: Rationing

\begin{tabular}{|c|c|c|c|c|c|c|}
\hline VARIABLES & $\begin{array}{c}(1) \\
\text { Probit } \\
\text { Rationing } \\
\end{array}$ & $\begin{array}{c}(2) \\
\text { Probit } \\
\text { Rationing } \\
\end{array}$ & $\begin{array}{c}(3) \\
\text { Probit } \\
\text { Rationing } \\
\end{array}$ & $\begin{array}{c}(4) \\
\text { Probit } \\
\text { Rationing } \\
\end{array}$ & $\begin{array}{c}(5) \\
\text { Probit } \\
\text { Rationing } \\
\end{array}$ & $\begin{array}{c}(6) \\
\text { Probit } \\
\text { Rationing } \\
\end{array}$ \\
\hline Relational lending & $\begin{array}{l}-0.032 \\
(0.056)\end{array}$ & $\begin{array}{c}0.001 \\
(0.066)\end{array}$ & $\begin{array}{l}-0.047 \\
(0.061)\end{array}$ & $\begin{array}{c}0.081 \\
(0.114)\end{array}$ & $\begin{array}{c}0.073 \\
(0.119)\end{array}$ & $\begin{array}{c}0.041 \\
(0.127)\end{array}$ \\
\hline Soft $\mathrm{x}$ Transactional lend. & & & & $\begin{array}{l}-0.238 \\
(0.185)\end{array}$ & $\begin{array}{l}-0.046 \\
(0.326)\end{array}$ & $\begin{array}{l}-0.019 \\
(0.365)\end{array}$ \\
\hline Soft $\mathrm{x}$ Relational lending & & & & $\begin{array}{c}-0.227^{*} \\
(0.136)\end{array}$ & $\begin{array}{l}-0.184 \\
(0.172)\end{array}$ & $\begin{array}{c}-0.212 \\
(0.217)\end{array}$ \\
\hline Age & $\begin{array}{c}0.000 \\
(0.002)\end{array}$ & $\begin{array}{c}0.000 \\
(0.002)\end{array}$ & $\begin{array}{c}0.001 \\
(0.001)\end{array}$ & $\begin{array}{c}0.000 \\
(0.002)\end{array}$ & $\begin{array}{c}0.000 \\
(0.002)\end{array}$ & $\begin{array}{c}0.001 \\
(0.001)\end{array}$ \\
\hline Leverage & $\begin{array}{c}3.120 * * * \\
(0.482)\end{array}$ & $\begin{array}{c}3.162 * * * \\
(0.527)\end{array}$ & $\begin{array}{c}3.549 * * * \\
(0.616)\end{array}$ & $\begin{array}{c}3.171 * * * \\
(0.526)\end{array}$ & $\begin{array}{c}3.166 * * * \\
(0.528)\end{array}$ & $\begin{array}{c}3.554 * * * \\
(0.623)\end{array}$ \\
\hline GDP 2009 & $\begin{array}{c}-0.000 * * * \\
(0.000)\end{array}$ & $\begin{array}{c}-0.000 * * * \\
(0.000)\end{array}$ & $\begin{array}{l}-0.000 \\
(0.000)\end{array}$ & $\begin{array}{c}-0.000 * * * \\
(0.000)\end{array}$ & $\begin{array}{c}-0.000 * * * \\
(0.000)\end{array}$ & $\begin{array}{l}-0.000 \\
(0.000)\end{array}$ \\
\hline Austria & $\begin{array}{c}0.708 * * * \\
(0.071)\end{array}$ & $\begin{array}{c}-0.931 * * * \\
(0.113)\end{array}$ & & $\begin{array}{c}-0.949 * * * \\
(0.128)\end{array}$ & $\begin{array}{c}-0.956 * * * \\
(0.127)\end{array}$ & \\
\hline France & $\begin{array}{c}1.325 * * * \\
(0.093)\end{array}$ & $\begin{array}{c}-0.164 * * * \\
(0.055)\end{array}$ & $\begin{array}{c}-0.266 * * * \\
(0.047)\end{array}$ & $\begin{array}{c}-0.168 * * * \\
(0.053)\end{array}$ & $\begin{array}{c}-0.161 * * * \\
(0.060)\end{array}$ & $\begin{array}{c}-0.264 * * * \\
(0.051)\end{array}$ \\
\hline Germany & $\begin{array}{c}0.075 \\
(0.056)\end{array}$ & $\begin{array}{c}-0.717 * * * \\
(0.032)\end{array}$ & $\begin{array}{c}-0.617 * * * \\
(0.020)\end{array}$ & $\begin{array}{c}-0.683 * * * \\
(0.035)\end{array}$ & $\begin{array}{c}-0.713 * * * * \\
(0.020)\end{array}$ & $\begin{array}{c}-0.616 * * * \\
(0.033)\end{array}$ \\
\hline Constant & $\begin{array}{c}3.279 * * * \\
(0.132)\end{array}$ & $\begin{array}{c}-2.072 * * * \\
(0.177)\end{array}$ & $\begin{array}{c}-2.551 * * * \\
(0.203)\end{array}$ & $\begin{array}{c}-2.176 * * * \\
(0.176)\end{array}$ & $\begin{array}{c}-2.112 * * * \\
(0.235)\end{array}$ & $\begin{array}{c}-2.592 * * * \\
(0.263)\end{array}$ \\
\hline Observations & 4,648 & 4,407 & 3,665 & 4,407 & 4,407 & 3,665 \\
\hline
\end{tabular}

Note: The table reports regressions coefficients. The dependent variable is reported at the top of each column. The regressions are estimated by Probit. Robust standard errors are reported below coefficients. $(*)$ : coefficient significant at $10 \%$ confidence level; $(* *)$ : coefficient significant at 5\% confidence level; (***): coefficient significant at less than $1 \%$ confidence level. 
Table 4: Weak Rationing

\begin{tabular}{|c|c|c|c|c|c|c|}
\hline VARIABLES & $\begin{array}{c}(1) \\
\text { Probit } \\
\text { Weak Rationing }\end{array}$ & $\begin{array}{c}(2) \\
\text { Probit } \\
\text { Weak Rationing }\end{array}$ & $\begin{array}{c}(3) \\
\text { Probit } \\
\text { Weak Rationing }\end{array}$ & $\begin{array}{c}(4) \\
\text { Probit } \\
\text { Weak Rationing }\end{array}$ & $\begin{array}{c}(5) \\
\text { Probit } \\
\text { Weak Rationing }\end{array}$ & $\begin{array}{c}(6) \\
\text { Probit } \\
\text { Weak Rationing }\end{array}$ \\
\hline Transactional lending & $\begin{array}{c}0.406 * * \\
(0.201)\end{array}$ & $\begin{array}{l}0.425^{*} \\
(0.218)\end{array}$ & $\begin{array}{c}0.301 \\
(0.194)\end{array}$ & $\begin{array}{c}0.569 * * \\
(0.245)\end{array}$ & $\begin{array}{c}0.702 * * \\
(0.311)\end{array}$ & $\begin{array}{c}0.545^{*} \\
(0.311)\end{array}$ \\
\hline Relational lending & $\begin{array}{c}0.114 \\
(0.170)\end{array}$ & $\begin{array}{c}0.130 \\
(0.175)\end{array}$ & $\begin{array}{c}0.061 \\
(0.128)\end{array}$ & $\begin{array}{c}0.121 \\
(0.217)\end{array}$ & $\begin{array}{c}0.146 \\
(0.228)\end{array}$ & $\begin{array}{c}0.112 \\
(0.185)\end{array}$ \\
\hline Soft Information & & $\begin{array}{l}-0.115 \\
(0.123)\end{array}$ & $\begin{array}{c}-0.088 \\
(0.106)\end{array}$ & & $\begin{array}{c}0.359 \\
(0.348)\end{array}$ & $\begin{array}{c}0.317 \\
(0.314)\end{array}$ \\
\hline Soft $\mathrm{x}$ Transactional lending & & & & $\begin{array}{c}-0.332 \\
(0.215)\end{array}$ & $\begin{array}{l}-0.686 \\
(0.442)\end{array}$ & $\begin{array}{c}-0.566 \\
(0.446)\end{array}$ \\
\hline Soft $\mathrm{x}$ Relational lending & & & & $\begin{array}{c}0.005 \\
(0.243)\end{array}$ & $\begin{array}{l}-0.132 \\
(0.265)\end{array}$ & $\begin{array}{c}-0.178 \\
(0.274)\end{array}$ \\
\hline Age & $\begin{array}{c}0.001 \\
(0.001)\end{array}$ & $\begin{array}{c}0.001 \\
(0.001)\end{array}$ & $\begin{array}{c}0.001 \\
(0.001)\end{array}$ & $\begin{array}{c}0.001 \\
(0.001)\end{array}$ & $\begin{array}{c}0.001 \\
(0.001)\end{array}$ & $\begin{array}{c}0.001 \\
(0.001)\end{array}$ \\
\hline Size (ln employees) & $\begin{array}{c}-0.060 * * * \\
(0.021)\end{array}$ & $\begin{array}{c}-0.073 * * * \\
(0.012)\end{array}$ & $\begin{array}{c}-0.067 * * * \\
(0.018)\end{array}$ & $\begin{array}{c}-0.073 * * * \\
(0.012)\end{array}$ & $\begin{array}{c}-0.074 * * * \\
(0.012)\end{array}$ & $\begin{array}{c}-0.067 * * * \\
(0.019)\end{array}$ \\
\hline Group & $\begin{array}{c}0.109 * * \\
(0.055)\end{array}$ & $\begin{array}{c}0.133^{*} \\
(0.068)\end{array}$ & $\begin{array}{l}0.156^{*} \\
(0.087)\end{array}$ & $\begin{array}{c}0.135 * * \\
(0.067)\end{array}$ & $\begin{array}{c}0.141 * * \\
(0.067)\end{array}$ & $\begin{array}{l}0.162^{*} \\
(0.085)\end{array}$ \\
\hline Leverage & $\begin{array}{c}1.737 * * \\
(0.722)\end{array}$ & $\begin{array}{l}1.761 * * \\
(0.728)\end{array}$ & $\begin{array}{c}2.027 * * \\
(0.824)\end{array}$ & $\begin{array}{c}1.748 * * \\
(0.741)\end{array}$ & $\begin{array}{l}1.762 * * \\
(0.735)\end{array}$ & $\begin{array}{c}2.033 * * \\
(0.829)\end{array}$ \\
\hline GDP 2009 & $\begin{array}{c}0.000 * * * \\
(0.000)\end{array}$ & $\begin{array}{c}0.000 * * * \\
(0.000)\end{array}$ & $\begin{array}{c}0.000 * * * \\
(0.000)\end{array}$ & $\begin{array}{c}0.000 * * * \\
(0.000)\end{array}$ & $\begin{array}{c}0.000 * * * \\
(0.000)\end{array}$ & $\begin{array}{c}0.000 * * * \\
(0.000)\end{array}$ \\
\hline Austria & $\begin{array}{c}-0.738 * * * \\
(0.046)\end{array}$ & $\begin{array}{c}-0.763 * * * \\
(0.086)\end{array}$ & $\begin{array}{c}-0.901 * * * \\
(0.077)\end{array}$ & $\begin{array}{c}-0.726 * * * \\
(0.086)\end{array}$ & $\begin{array}{c}-0.765^{* * *} * \\
(0.062)\end{array}$ & $\begin{array}{c}-0.895 * * * \\
(0.061)\end{array}$ \\
\hline France & $\begin{array}{c}-0.689 * * * \\
(0.073)\end{array}$ & $\begin{array}{c}-0.735 * * * \\
(0.061)\end{array}$ & $\begin{array}{c}-0.792 * * * \\
(0.043)\end{array}$ & $\begin{array}{c}-0.713 * * * \\
(0.059)\end{array}$ & $\begin{array}{c}-0.645^{* * *} \\
(0.097)\end{array}$ & $\begin{array}{c}-0.710 * * * \\
(0.090)\end{array}$ \\
\hline Germany & $\begin{array}{c}0.740 * * * \\
(0.230)\end{array}$ & $\begin{array}{c}0.801 * * * \\
(0.233)\end{array}$ & $\begin{array}{c}1.112 * * * \\
(0.221)\end{array}$ & $\begin{array}{c}0.689 * * \\
(0.316)\end{array}$ & $\begin{array}{c}0.730 * * * \\
(0.260)\end{array}$ & $\begin{array}{c}1.024 * * * \\
(0.268)\end{array}$ \\
\hline Hungary & $\begin{array}{c}-0.004 \\
(0.058)\end{array}$ & $\begin{array}{c}0.012 \\
(0.058)\end{array}$ & $\begin{array}{c}0.036 \\
(0.054)\end{array}$ & $\begin{array}{c}0.001 \\
(0.066)\end{array}$ & $\begin{array}{c}0.006 \\
(0.058)\end{array}$ & $\begin{array}{c}0.029 \\
(0.056)\end{array}$ \\
\hline Spain & $\begin{array}{c}-0.864 * * * \\
(0.059)\end{array}$ & $\begin{array}{c}-0.950 * * * \\
(0.061)\end{array}$ & & $\begin{array}{c}-0.955^{* * *} * \\
(0.066)\end{array}$ & $\begin{array}{c}-0.951 * * * \\
(0.067)\end{array}$ & \\
\hline Labour Productivity & & & $\begin{array}{c}-0.001 \\
(0.001)\end{array}$ & & & $\begin{array}{c}-0.001 \\
(0.001)\end{array}$ \\
\hline Capital Intensity & & & $\begin{array}{c}0.001 * * * \\
(0.000)\end{array}$ & & & $\begin{array}{c}0.001 * * * \\
(0.000)\end{array}$ \\
\hline Constant & $\begin{array}{c}-3.314^{* * *} * \\
(0.457)\end{array}$ & $\begin{array}{c}-3.423^{* * *} * \\
(0.409)\end{array}$ & $\begin{array}{c}-4.063 * * * \\
(0.456)\end{array}$ & $\begin{array}{c}-3.371 * * * \\
(0.484)\end{array}$ & $\begin{array}{c}-3.555^{* * * *} \\
(0.370)\end{array}$ & $\begin{array}{c}-4.182 * * * \\
(0.414)\end{array}$ \\
\hline Observations & 4,648 & 4,584 & 3,804 & 4,584 & 4,584 & 3,804 \\
\hline
\end{tabular}

Note: The table reports regressions coefficients. The dependent variable is reported at the top of each column. The regressions are estimated by Probit. Robust standard errors are reported below coefficients. $(*)$ : coefficient significant at $10 \%$ confidence level; (**): coefficient significant at $5 \%$ confidence level; $(* * *)$ : coefficient significant at less than $1 \%$ confidence level. 
Table 5: Strong Rationing

\begin{tabular}{|c|c|c|c|c|c|c|}
\hline VARIABLES & $\begin{array}{c}(1) \\
\text { Probit } \\
\text { Strong } \\
\text { Rationing }\end{array}$ & $\begin{array}{c}(2) \\
\text { Probit } \\
\text { Strong } \\
\text { Rationing }\end{array}$ & $\begin{array}{c}(3) \\
\text { Probit } \\
\text { Strong } \\
\text { Rationing }\end{array}$ & $\begin{array}{c}(4) \\
\text { Probit } \\
\text { Strong } \\
\text { Rationing }\end{array}$ & $\begin{array}{c}(5) \\
\text { Probit } \\
\text { Strong } \\
\text { Rationing }\end{array}$ & $\begin{array}{c}(6) \\
\text { Probit } \\
\text { Strong } \\
\text { Rationing }\end{array}$ \\
\hline Transactional lending & $\begin{array}{c}0.548 * * * \\
(0.156)\end{array}$ & $\begin{array}{c}0.570 * * * \\
(0.169)\end{array}$ & $\begin{array}{c}0.488 * * * \\
(0.137)\end{array}$ & $\begin{array}{c}0.611 * * * \\
(0.236)\end{array}$ & $\begin{array}{c}0.543^{*} \\
(0.291)\end{array}$ & $\begin{array}{c}0.408 \\
(0.304)\end{array}$ \\
\hline Relational lending & $\begin{array}{c}0.015 \\
(0.068)\end{array}$ & $\begin{array}{c}0.047 \\
(0.073)\end{array}$ & $\begin{array}{c}0.051 \\
(0.133)\end{array}$ & $\begin{array}{c}0.206 \\
(0.175)\end{array}$ & $\begin{array}{c}0.198 \\
(0.175)\end{array}$ & $\begin{array}{c}0.214 \\
(0.185)\end{array}$ \\
\hline Soft Information & & $\begin{array}{c}-0.278 * \\
(0.148)\end{array}$ & $\begin{array}{c}-0.282 * \\
(0.162)\end{array}$ & & $\begin{array}{c}-0.176 \\
(0.211)\end{array}$ & $\begin{array}{c}-0.270 \\
(0.211)\end{array}$ \\
\hline Soft x Transactional lend. & & & & $\begin{array}{l}-0.152 \\
(0.184)\end{array}$ & $\begin{array}{c}0.041 \\
(0.385)\end{array}$ & $\begin{array}{c}0.179 \\
(0.414)\end{array}$ \\
\hline Soft $\mathrm{x}$ Relational lending & & & & $\begin{array}{c}-0.422 \\
(0.281)\end{array}$ & $\begin{array}{c}-0.384 \\
(0.276)\end{array}$ & $\begin{array}{l}-0.392 * \\
(0.206)\end{array}$ \\
\hline Age & $\begin{array}{l}-0.001 \\
(0.002)\end{array}$ & $\begin{array}{l}-0.001 \\
(0.002)\end{array}$ & $\begin{array}{l}-0.000 \\
(0.002)\end{array}$ & $\begin{array}{c}-0.001 \\
(0.002)\end{array}$ & $\begin{array}{l}-0.001 \\
(0.002)\end{array}$ & $\begin{array}{l}-0.000 \\
(0.002)\end{array}$ \\
\hline Size (ln employees) & $\begin{array}{c}0.069 * * * \\
(0.022)\end{array}$ & $\begin{array}{c}0.062 * * * \\
(0.021)\end{array}$ & $\begin{array}{c}0.046 \\
(0.030)\end{array}$ & $\begin{array}{c}0.063 * * * \\
(0.022)\end{array}$ & $\begin{array}{c}0.063 * * * \\
(0.022)\end{array}$ & $\begin{array}{c}0.047 \\
(0.031)\end{array}$ \\
\hline Group & $\begin{array}{c}0.066 \\
(0.066)\end{array}$ & $\begin{array}{c}0.063 \\
(0.070)\end{array}$ & $\begin{array}{c}0.120 * * \\
(0.054)\end{array}$ & $\begin{array}{c}0.071 \\
(0.063)\end{array}$ & $\begin{array}{c}0.068 \\
(0.064)\end{array}$ & $\begin{array}{c}0.124 * * \\
(0.055)\end{array}$ \\
\hline Leverage & $\begin{array}{c}3.365^{* * *} * \\
(0.525)\end{array}$ & $\begin{array}{c}3.435 * * * \\
(0.572)\end{array}$ & $\begin{array}{c}3.576 * * * \\
(0.770)\end{array}$ & $\begin{array}{c}3.452 * * * \\
(0.575)\end{array}$ & $\begin{array}{c}3.447 * * * \\
(0.577)\end{array}$ & $\begin{array}{c}3.586 * * * \\
(0.787)\end{array}$ \\
\hline GDP 2009 & $\begin{array}{c}-0.000 * * * \\
(0.000)\end{array}$ & $\begin{array}{c}-0.000 * * * \\
(0.000)\end{array}$ & $\begin{array}{c}-0.000 * \\
(0.000)\end{array}$ & $\begin{array}{c}-0.000 * * * \\
(0.000)\end{array}$ & $\begin{array}{c}-0.000 * * * \\
(0.000)\end{array}$ & $\begin{array}{l}-0.000^{*} \\
(0.000)\end{array}$ \\
\hline France & $\begin{array}{c}1.091 * * * * \\
(0.047)\end{array}$ & $\begin{array}{c}0.111 * * \\
(0.056)\end{array}$ & $\begin{array}{l}-0.096 \\
(0.132)\end{array}$ & $\begin{array}{c}0.115 * * \\
(0.057)\end{array}$ & $\begin{array}{l}0.123^{*} \\
(0.063)\end{array}$ & $\begin{array}{l}-0.087 \\
(0.137)\end{array}$ \\
\hline Germany & $\begin{array}{c}-0.125^{*} \\
(0.066)\end{array}$ & $\begin{array}{c}-0.686 * * * \\
(0.043)\end{array}$ & $\begin{array}{c}-0.693 * * * \\
(0.074)\end{array}$ & $\begin{array}{c}-0.663 * * * \\
(0.047)\end{array}$ & $\begin{array}{c}-0.690 * * * \\
(0.075)\end{array}$ & $\begin{array}{c}-0.712 \text { *** } \\
(0.102)\end{array}$ \\
\hline Hungary & $\begin{array}{c}-3.274 * * * \\
(0.146)\end{array}$ & $\begin{array}{c}-1.140 * * * \\
(0.124)\end{array}$ & $\begin{array}{c}-0.863 * * * \\
(0.206)\end{array}$ & $\begin{array}{c}-1.150 * * * \\
(0.116)\end{array}$ & $\begin{array}{c}-1.152 * * * \\
(0.118)\end{array}$ & $\begin{array}{c}-0.889 * * * \\
(0.207)\end{array}$ \\
\hline Spain & $\begin{array}{c}-0.371 * * * \\
(0.032)\end{array}$ & & & & & \\
\hline Labour Productivity & & & $\begin{array}{l}-0.002 \\
(0.001)\end{array}$ & & & $\begin{array}{l}-0.002 \\
(0.001)\end{array}$ \\
\hline Capital Intensity & & & $\begin{array}{c}0.000 \\
(0.000)\end{array}$ & & & $\begin{array}{c}0.000 \\
(0.000)\end{array}$ \\
\hline Constant & $\begin{array}{c}1.730 * * * \\
(0.097)\end{array}$ & $\begin{array}{c}-1.838 * * * \\
(0.226)\end{array}$ & $\begin{array}{c}-2.303 * * * \\
(0.123)\end{array}$ & $\begin{array}{c}-1.951 * * * \\
(0.264)\end{array}$ & $\begin{array}{c}-1.888^{* * *} * \\
(0.267)\end{array}$ & $\begin{array}{c}-2.319 * * * \\
(0.176)\end{array}$ \\
\hline Observations & 4,588 & 4,347 & 3,665 & 4,347 & 4,347 & 3,665 \\
\hline
\end{tabular}

Note: The table reports regressions coefficients. The dependent variable is reported at the top of each column. The regressions are estimated by Probit. Robust standard errors are reported below coefficients. $(*)$ : coefficient significant at $10 \%$ confidence level; (**): coefficient significant at $5 \%$ confidence level; $(* * *)$ : coefficient significant at less than $1 \%$ confidence level. 


\section{Appendix: Survey questions}

F12. Which factors are key in the choice of a main bank?

- the bank offers competitive services and funding

- the bank offers efficient internet services

- the bank's lending criteria is clear and transparent

- the bank is conveniently located

- the bank has an extensive international network

- the bank offers also a consultancy on strategic financial decisions

- the bank has a long-lasting relationship with the firm

- the bank has flexible procedures/not constrained by red tape

- it was the Group's main bank

F16. Which type of information does the bank normally uselask to assess your firm's credit worthiness?

- Collateral

- Balance sheet information

- Interviews with management on firm's policy and prospects

- Business plan and firms' targets

- Historical records of payments and debt service

- Brand recognition

- Other 